\title{
KEWENANGAN NOTARIS DALAM MEMBUAT SURAT KETERANGAN HAK WARIS BAGI ANAK YANG DILAHIRKAN PADA HUBUNGAN SEDARAH
}

Oleh:

\author{
Amalia Putri Vairus \\ Email : Amelvairus7@gmail.com \\ Fakultas Hukum Universitas Jember \\ Dyah Ochtorina Susanti \\ Email : dyahochtorina.fh@unej.ac.id \\ Fakultas Hukum Universitas Jember \\ Rahmadi Indra Tektona \\ Email : rahmadiindra@unej.ac.id \\ Fakultas Hukum Universitas Jember
}

\begin{abstract}
Abstrak
Kewenangan notaris secara umum terdapat dalam Pasal 15 UUJN yaitu membuat akta otentik. Terkait kewenangan notaris dalam membuat surat keterangan waris tidak diatur secara spesifik dalam Pasal tersebut yang mengakibatkan ketidakpastian hukum dalam pembuatan surat keterangan waris khususnya bagi anak yang dilahirkan pada hubungan sedarah. Tujuan dalam penelitian ini yaitu untuk menemukan mengenai pengaturan ke depan terhadap kewenangan notaris dalam membuat surat keterangan hak waris bagi anak yang dilahirkan pada hubungan sedarah (Anak Sumbang). Pada penelitian ini digunakan pendekatan yuridis normatif. Hasil dari penelitian ini adalah diperlukannya pengaturan kedepan mengenai kewenangan notaris dalam membuat surat keterangan waris bagi anak yang dilahirkan pada hubungan sedarah (Anak Sumbang) yang dikaji menggunakan teori kepastian hukum.
\end{abstract}

Kata Kunci: Kewenangan Notaris, Surat Keterangan Waris, Anak Sumbang

\begin{abstract}
In general, the authority of a notary is contained in Article 15 of the UUJN, namely making an authentic deed. Regarding the authority of a notary in making an inheritance certificate, it is not specifically regulated in the article which results in legal uncertainty in making an inheritance certificate, especially for children born in blood relations. The purpose of this study is to find out about future arrangements for the authority of a notary in making a certificate of inheritance rights for children born in incest (Sumbang Children). In this study, a normative juridical approach was used. The results of this study are the need for future arrangements regarding the authority of a notary in making a certificate of inheritance for children born in incest (Children Contribute) which is studied using legal certainty theory.
\end{abstract}

Keywords: Authority of Notary, Certificate of Inheritance, Donated Child 


\section{PENDAHULUAN}

\subsection{Latar Belakang}

Ahli waris merupakan orang yang berhak dalam memperoleh harta waris. Terkait untuk membuktikan bahwa seseorang merupakan ahli waris yang sah, dibutuhkan adanya dokumen yang membuktikan kedudukan sebagai ahli waris tersebut. Dokumen tersebut dinamakan surat keterangan waris. Menurut Peraturan Menteri Negara Agraria/Kepala Badan Pertanahan Nasional Nomor 3 Tahun 1997 Tentang Ketentuan Pelaksanaan Peraturan Pemerintah Nomor 24 Tahun 1997 tentang Pendaftaran Tanah, pada Pasal 111 ayat 1 dinyatakan bahwa bagi Warga Negara Indonesia (WNI) golongan Eropa, Cina atau Tionghoa, surat keterangan warisnya dibuat oleh notaris. Bagi golongan Timur Asing, surat keterangan warisnya dibuat oleh Balai Harta Peninggalan (BHP), sedangkan bagi golongan penduduk pribumi, surat keterangan warisnya dibuat dibawah tangan, bermaterai, diketahui oleh lurah dan camat berdasarkan tempat tinggal terakhir pewaris. ${ }^{1}$

Pembuatan surat keterangan waris bagi golongan penduduk Eropa, Cina atau Tionghoa dan Timur Asing kecuali orang Arab yang beragama Islam oleh Notaris

\footnotetext{
1 Gede Afriliana Saputra, Dasar Hukum Notaris dalam Pembuatan Surat Keterangan Waris, Jurnal Ilmiah Prodi Magister Kenotariatan, Tahun 2015
}

berlangsung hingga diberlakukannya Undang-Undang Nomor 30 Tahun 2004 tentang Jabatan Notaris (selanjutnya disebut UUJN). Kewenangan notaris secara umum diatur dalam Pasal 15 ayat 1 UUJN yang menyatakan:

Notaris berwenang membuat akta otentik mengenai semua perbuatan, perjanjian, dan ketetapan yang diharuskan oleh peraturan perundang-undangan dan/atau yang dikehendaki oleh yang berkepentingan untuk dinyatakan dalam akta otentik, menjamin kepastian tanggal pembuatan akta, menyimpan akta, memberikan grosse, salinan dan kutipan akta, semuanya itu sepanjang pembuatan akta-akta itu tidak juga ditugaskan atau dikecualikan kepada pejabat lain atau orang lain yang ditetapkan oleh undang-undang

Kewenangan notaris dalam membuat surat keterangan waris, tidak diatur secara spesifik dalam Pasal 15 UUJN. Peraturan mengenai surat keterangan waris terdapat dalam Peraturan Menteri Negara Agraria/ Kepala Badan Pertanahan Nasional Nomor 3 Tahun 1997 Tentang Ketentuan Pelaksanaan Peraturan Pemerintah Nomor 24 Tahun 1997 tentang Pendaftaran Tanah. Pada Pasal 111 ayat 1 huruf c Peraturan Menteri ini menyatakan bahwa bagi warga negara Indonesia keturunan Tionghoa, akta 
keterangan warisnya dibuat oleh Notaris. ${ }^{2}$ Berdasarkan Pasal 7 ayat 1 Undang-Undang Nomor 12 Tahun 2011 tentang Pembentukan Peraturan Perundang-Undangan, Peraturan Menteri tersebut tidak termasuk dalam kategori peraturan perundangundangan menurut UU Pembentukan Peraturan Perundang-undangan. Peraturan Menteri tersebut juga berlaku intern dalam arti keputusan tidak mengikat secara umum sehingga tidak dapat dijadikan dasar hukum bagi notaris dalam membuat surat keterangan waris. ${ }^{3}$

Permasalahan yang sering terjadi pada masa kini yaitu mengenai hak waris anak dari perkawinan sedarah (Anak Sumbang). Manusia cenderung tidak lagi mentaati norma-norma yang ada di dalam masyarakat, baik norma agama, sosial maupun moral. Perubahan sosial terjadi seiring dengan perkembangan teknologi sehingga begitu mudahnya budaya-budaya baru atau asing masuk dan merusak budaya-budaya yang telah ada dalam masyarakat. Perkawinan sedarah (incest) banyak ditemui di beberapa daerah di Indonesia. Perkawinan sedarah (incest) adalah hubungan batin yang bersifat seksual antara pasangan yang masih memiliki hubungan darah, seperti seorang ayah yang menikahi anak perempu-

${ }^{2}$ Gede Afriliana Saputra, Dasar Hukum Notaris dalam Pembuatan Surat Keterangan Waris, Jurnal Ilmiah Prodi Magister Kenotariatan, h. 220

${ }^{3}$ Maria Farida, Ilmu Perundang-Undangan, DasarDasar dan Pembentukannya (Yogyakarta: Kanisius, 2002), h. 78 an kandungnya, ibu yang menikah dengan anak laki-laki kandungnya, dan saudara laki-laki yang menikahi saudara perempuan kandungnya. Peristiwa tersebut di negara Indonesia masih dianggap tabu dan tidak ada aturan yang membenarkan pernikahan sedarah (incest). ${ }^{4}$ Perkawinan sedarah di larang di Indonesia karna melanggar norma-norma yang ada dalam masyarakat, sebagaimana dinyatakan dalam Pasal 28B ayat (1) Undangg-Undang Dasar Republik Indonesia Tahun 1945 yang menyatakan, "setiap orang berhak mem-bentuk keluarga dan melanjutkan keturunan melalui perkawinan yang sah". 5 Terkait itu, terdapat ketidakpastian hukum terkait kewenangan notaris dalam pembuatan surat keterangan waris khususnya bagi anak yang lahir dari hubungan sedarah.

\subsection{Rumusan Masalah}

Berdasarkan latar belakang tersebut diatas, sehingga kesimpulan permasalahan dalam penulisan ini yaitu, Bagaimana Pengaturan Kedepan Terhadap Kewenangan Notaris Dalam Membuat Surat Keterangan Hak Waris Bagi Anak Yang Dilahirkan Pada Hubungan Sedarah (Anak Sumbang).

\footnotetext{
4 Ritna Makdalena, Tinjauan Yuridis Tentang Perkawinan Sedarah Menurut UU Nomor 1 Tahun 1974, Jurnal Lex Privatum, Vol. VI, No. 2, 2018, h. 102.

5 Lihat ketentuan Pasal 28B ayat (1) UndanggUndang Dasar Republik Indonesia Tahun 1945
} 
Hasil penelitian ini secara teoritis harus memberikan sumbangan gagasan kepada hukum secara umum dan khususnya pada notaris dalam membuat surat keterangan waris. Adapun tujuan dalam penulisan ini yaitu untuk menemukan mengenai pengaturan ke depan terhadap kewenangan notaris dalam membuat surat keterangan hak waris bagi anak yang dilahirkan pada hubungan sedarah (Anak Sumbang).

\section{METODE PENELITIAN}

Tipe penelitian yang digunakan dalam penulisan ini yaitu tipe penelitian yang bersifat yuridis normatif (legal research), yaitu penelitian yang difokuskan untuk mengkaji penerapan kaidah-kaidah atau norma-norma dalam hukum positif. ${ }^{6}$ Tipe penelitian yuridis normatif dilakukan dengan cara mengkaji berbagai aturan hukum yang bersifat formil seperti undangundang, peraturan-peraturan serta literatur yang berisi konsep-konsep teoritis yang kemudian dihubungkan dengan permasalahan yang akan di bahas dalam tesis ini yaitu mengenai pengaturan ke depan terhadap kewenangan notaris dalam membuat surat keterangan hak waris bagi anak yang dilahirkan pada hubungan sedarah (Anak Sumbang).

\footnotetext{
${ }^{6}$ Herowati Poesoko, Diktat Mata Kuliah Metode Penulisan dan Penelitian Hukum (Fakultas Hukum Universitas Jember, 2012), h. 34-35.
}

\section{PEMBAHASAN}

\subsection{Ketidakadilan Peraturan Hukum} Indonesia Terhadap Anak Sumbang

Pada waktu UU Perkawinan dirumuskan belum terpikirkan oleh para pembentuk undang-undang bahwa orang akan bisa membuktikan asal usul keturunan terhadap anak yang lahir diluar perkawinan, terutama jika si perempuan pernah melakukan hubungan seksual dengan lebih dari seorang laki-laki. Walaupun mungkin pihak perempuan dapat memperkirakan siapa ayah dari anak yang dikandungnya, namun hal itu tidak dapat dijadikan bukti secara hukum yang bantuan ilmu dapat menunjukan siapa sebenarnya ayah biologis si anak. Majelis Hakim Konstitusi memberikan pertimbangan yang cukup progresif menyangkut persoalan tersebut, dimana pembuktian silsilah keturunan melalui pengetahuan dan teknologi mulai diakomodir oleh Mahkamah Konstitusi sebagai bentuk upaya yang dapat dilakukan oleh si anak dan ibu kandungnya dalam memastikan siapa ayah biologis si anak. ${ }^{7}$ Mengenai hal itu Majelis Konstitusi memberikan pertimbangan sebagai berikut: ${ }^{8}$

Menimbang bahwa pokok permasalahan hukum mengenai anak yang di-

\footnotetext{
${ }^{7}$ Witanto, Tanggung Jawab Notaris dalam Membuat Surat Keterangan Hak Waris (Jakarta: Tesis, 2008), h.232

${ }^{8}$ Lihat putusan Mahkamah Konstitusi No. 46/PUUVIII/2010
} 
lahirkan di luar perkawinan adalah mengenai makna hukum (legal meaning) frasa "yang dilahirkan di luar perkawinan. Untuk memperoleh jawaban dalam perspektif yang lebih luas perlu dijawab pula permasalahan terkait, yaitu permasalahan tentang sahnya anak. Secara alamiah, tidaklah mungkin seorang perempuan hamil tanpa terjadinya pertemuan antara ovum dan spermatozoa baik melalui hubungan seksual (coitus) maupun melalui cara lain berdasarkan perkembangan teknologi yang menyebabkan terjadinya pembuahan.

Terkait itu, tidak tepat dan tidak adil manakala hukum menetapkan bahwa anak yang lahir dari suatu kehamilan karena hubungan seksual di luar perkawinan hanya memiliki hubungan dengan perempuan tersebut sebagai ibunya. Adalah tidak tepat dan tidak adil pula jika hukum membebaskan laki-laki yang melakukan hubungan seksual yang menyebabkan terjadinya kehamilan dan kelahiran anak tersebut dari tanggung jawabnya sebagai seorang bapak dan bersamaan dengan itu hukum meniadakan hak-hak anak terhadap lelaki tersebut sebagai bapaknya. Lebih-lebih manakala berdasarkan perkembangan teknologi yang ada itu merupakan anak dari laki-laki tertentu memungkinkan dapat dibuktikan bahwa seorang anak itu merupakan anak dari laki-laki tertentu. Untuk mencapai tingkat kesempurnaan sebuah aturan hukum, maka hukum harus bersentuhan dengan bidang-bidang ilmu yang lain, terutama dalam hal pembuktian agar persoalan hukum yang terjadi bisa lebih terang dan jelas. Bukan hal yang baru dalam proses penegakan hukum menggunakan peran dari bidang-bidang keilmuan lain, sehingga dalam kaitannya dengan asal usul keturunan orang dapat menggunakan ahli ilmu genetika untuk melakukan pencocokan DNA si anak dengan laki-laki yang ditunjuk sebagai ayah biologisnya, jika hasil pemeriksaannya menunjukan persesuaian, maka asal usul keturunan dapat di buktikan dihadapan hukum. Pada dunia ilmu pengetahuan forensik, test DNA memungkinkan seseorang dapat diketahui memiliki kekerabatan dengan siapa. Tes DNA dilakukan dengan cara mengambil mitokondria seseorang untuk mengidentifikasi apakah seseorang memiliki hubungan keluarga dengan pihak ibu atau hubungan secara maternal. Caranya adalah dengan membandingkan DNA mitokondria yang dimilikinya dengan ibu kandung, nenek atau saudara kandung dari ibu. Karena seorang ibu menurunkan secara penuh DNA mitokondria kepada anaknya. Seorang ayah akan mewariskan kromosom Y pada anak laki-lakinya (karena kromosom Y hanya dimiliki laki-laki yang kromosom seksnya XY). Sedangkan anak 
perempuan tidak memiliki kromosom Y (kromosom seks perempuan XX). ${ }^{9}$

Setiap anak yang dilahirkan ke dunia memiliki fitrah yang sama sebagai makhluk Tuhan YME. Pasal 28 B ayat 2 UUD 1945 menyebutkan pada intinya bahwa setiap anak berhak atas kelangsungan hidup tumbuh dan berkembang serta berhak atas perlindungan dari kekerasan dan diskriminasi. Konstitusi tidak memberikan pengecualian atas hak asasi yang disandang oleh setiap anak, tidak terkecuali apakah dia sebagai anak yang sah atau anak luar kawin, bahkan kalimat berhak atas perlindungan dari kekerasan dan diskriminasi, sesungguhnya menunjukan bahwa negara pada prinsipnya melarang adanya pengelompokan status terhadap seorang anak, karena dengan adanya status dan kedudukan anak yang berbeda dimata hukum sesungguhnya negara telah melakukan diskriminasi terhadap anak yang menjadi warganya. Sedangkan menurut ketentuan Pasal 1 angka (3) UU No. 39 Tahun 1999 tentang Hak Asasi Manusia, bahwa yang dimaksud dengan diskriminasi adalah aetiap pembatasan, pelecehan, atau pengucilan yang langsung ataupun tak langsung didasarkan pada pembedaan manusia atas dasar agama, suku, ras, etnik, kelompok, golongan, status sosial, status ekonomi, jenis kelamin, bahasa, keyakinan politik, yang berakibat

\footnotetext{
${ }^{9}$ Witanto, op. cit, h. 234
}

penyimpangan atau penghapusan pengakuan, pelaksanaan atau penggunaan hak asasi manusia dan kebebasan dasar dalam kehidupan baik individual maupun kolektif dalam bidang politik, ekonomi, pengurangan, hukum, sosial, budaya, dan aspek kehidupan lainnya. ${ }^{10}$

Selanjutnya Undang-Undang No. 39 Tahun 1999 tentang Hak Asas tentang hak asasi dalam bagian ke-sepuluh mengatur secara khusus tentang hak asasi anak, terdapat 15 pasal yang mengatur tentang hak anak baik dalam kedudukannya sebagai warga negara maupun sebagai manusia antara lain sebagai berikut: Pasal 52 (1) Setiap anak berhak atas perlindungan oleh orangtua, keluarga, masyarakat, dan negara. (2) Hak anak adalah hak asasi manusia dan untuk kepentingannya hak anak itu diakui dan dilindungi oleh hukum bahkan sejak dalam kandungan.

Jika disimak pasal diatas, maka tidak satupun menyebutkan bahwa ketentuan tersebut hanya berlaku bagi anak yang sah atau anak yang dilahirkan dari perkawinan yang sah, atau setidaknya mengandung pengertian bahwa anak diluar kawin tidak termasuk anak yang dilindungi oleh aturanaturan di atas. Pokok persoalan tentang ketidakadilan dalam Pasal 43 ayat 1 itu bertumpu pada alasan bahwa hukum meniadakan hak-hak keperdataan si anak

${ }^{10}$ Ibid, h. 236. 
terhadap ayah biologisnya, hubungan anak dengan laki-laki sebagai ayah biologisnya tidak semata-mata karena adanya ikatan perkawinan, tetapi dapat juga didasarkan pada pembuktian adanya hubungan darah antara anak dengan ayahnya.

Terlepas dari soal prosedur administrasi perkawinannya, anak yang dilahirkan harus mendapatkan haknya yang sama dengan anak-anak pada umumnya yang dilahirkan dari suatu perkawinan yang sah. Jika hal itu tidak demikian, maka atas ketidakadilan itu, akan menimbulkan dampak bagi si anak, yang sesungguhnya tidak pernah meminta untuk dilahirkan ke dunia. Setiap anak tidak menanggung dosa atas kelahirannya, sehingga ia juga tidak boleh menerima diskriminasi secara hukum, apalagi jika melihat fakta sosial di masyarakat anak yang dilahirkan tanpa memiliki kejelasan status ayahnya sering mendapatkan perlakuan yang tidak adil dan stigma di masyarakat. $^{11}$

Ketentuan Pasal 43 Ayat (1) UU Perkawinan selain telah bertentangan dengan Konstitusi Pasal 28 B ayat (2) dan Pasal 28 D ayat (1) UUD 1945 juga bertentangan dengan ketentuan Pasal $28 \mathrm{C}$, Pasal 52 Ayat (1) dan Pasal 57 ayat (1) karena beberapa aturan tersebut mengandung makna yang saling bertentangan. Bukti pertentangan tersebut antara lain:

\footnotetext{
${ }^{11}$ Ibid, h. 242.
}

Ketentuan Pasal 43 ayat (1) UU perkawinan menentukan bahwa seorang ayah biologis sama sekali tidak bertanggung jawab dan tidak bisa dimintakan pertanggungjawabannya secara perdata atas anak yang lahir dari benihnya diluar perkawinan, padahal Konstitusi menghendaki bahwa setiap anak tanpa terkecuali apakah anak yang lahir dari perkawinan yang sah ataukah tidak harus mendapat perlindungan dan status secara hukum. Tidak adil jika hukum hanya melihat persoalan lahirnya anak hanya sekedar dari proses perkawinan orang tua si anak, padahal si anak tidak pernah memiliki kekuasaan apa-apa untuk memaksa orang tuanya agar melakukan perkawinan terlebih dahulu sebelum melahirkannya ke dunia. ${ }^{12}$

Kelahiran seorang anak tidak terjadi begitu saja, seorang laki-laki dengan seorang perempuan, lalu akan terjadi pembuahan secara biologis antara sel telur perempuan dengan sel sperma laki-laki. Peran laki-laki dan perempuan dalam proses kehamilan dan kelahiran anak memiliki porsi yang seimbang, sehingga selayaknya hukum tetap memberikan proses kehamilan dan kelahiran anak memiliki porsi yang beban dan tanggung jawab yang seimbang pula kepada Hukum saat ini telah menunjukan tindakan yang tidak adil keduanya manakala hasil dari

\footnotetext{
${ }^{12}$ Ibid
} 
perbuatannya itu lahir ke dunia. dimana pihak laki-laki dapat terbebas dari pertanggungjawaban secara perdata terhadap kelahiran anak yang berasal dari benihnya. Tidak ada seorang anak pun yang meminta untuk dilahirkan dan tidak ada seorang anak pun yang akan mau untuk dilahirkan dalam kondisi yang tidak sempurna secara hukum jika sebelum ia lahir Tuhan memberikan kesempatan terlebih dahulu untuk memilih akan dilahirkan dari rahim ibu yang mana, maka tidak akan ada yang mau untuk dilahirkan dari hasil hubungan yang tidak sah. Semua terjadi atas kekuasaan Tuhan tanpa bisa memilih dan menolaknya. Ketentuan yang membedakan perlakuan antara anak yang sah dengan anak luar kawin sesungguhnya akan menciderai makna keadilan dalam konstitusi. ${ }^{13}$

Memang harus diakui bahwa, sangat sulit untuk memberikan kedudukan yang benar-benar sama dan seimbang antara anak sah dengan anak luar kawin, karena tidak dapat dipungkiri bahwa diantara beberapa hal yang tidak mungkin dibedakan menyangkut fitrahnya sebagai manusia, keduanya tetap mengandung perbedaan, namun walaupun demikian, setidaknya perbedaan itu tidak menimbulkan rusaknya masa depan si anak, dimana kita ketahui bahwa setiap anak akan dalam beban yang berat menanggung menyongsong kehidupannya

\footnotetext{
${ }^{13}$ Ibid, h. 243.
}

yang panjang baik secara ekonomi maupun sosial. Seorang anak luar kawin juga harus mendapatkan haknya untuk bisa hidup secara layak dari ayah biologisnya, seperti biaya pemeliharaan dan pendidikan yang akan menunjang kehidupannya, atau setidaknya ia mendapat bagian dari harta peninggalan jika ayah biologisnya meninggal, walaupun bagiannya tidak sebesar bagian yang diterima oleh anak-anak yang sah, baik dengan waris, hibah, sedekah maupun wasiat. Untuk persoalan hak waris mungkin kita bisa melihat ketentuan KUH Perdata yang mengatur tentang hak bagian waris anak luar kawin yang diakui sebagaimana diatur dalam Pasal $863 \mathrm{KUH}$ Perdata yang berbunyi sebagai berikut: ${ }^{14}$

Bila yang meninggal itu meninggalkan keturunan sah menurut undang-undang atau suami isteri, maka anak-anak diluar kawin itu mewarisi sepertiga dari bagian yang sedianya mereka terima, seandainya mereka adalah anak-anak sah menurut undang-undang mereka mewarisi separuh dari harta peninggalan bila yang meninggal itu tidak meninggalkan keturunan suami atau isteri, tetapi meninggalkan keluarga sedarah dalam garis keatas atau saudara laki-laki dan perempuan atau keturunan-keturunan mereka dan tiga perempat bila hanya tinggal keluarga

\footnotetext{
${ }^{14}$ Lihat ketentuan Pasal 863 KUH Perdata
} 
sedarah yang masih hidup dalam derajat yang lebih jauh.

Anak dan segala kepentingannya harus dipisahkan dari setiap persengketaan yang terjadi pada kedua orang tuanya, urusan sah atau tidaknya perkawinan yang dilakukan oleh orang tuanya, atau bahkan sama sekali tidak ada perkawinan yang telah mendahuli proses kelahiran si anak, hak dan kedudukan si anak dimata hukum tidak boleh dirugikan, karena si anak tidak pernah terlibat atas segala kesalahan/dosa yang dilakukan oleh orang tuanya, hal tersebut dapat kita lihat dari penggalan bunyi pertimbangan Mahkamah Konstitusi sebagai hukum harus memberi perlindungan dan kepastian hukum yang adil terhadap status seorang anak yang dilahirkan dan hak-hak yang ada padanya, termasuk terhadap anak yang dilahirkan meskipun keabsahan perkawinannya masih dipersengketakan.

Pendapat Mahkamah Konstitusi dalam pertimbangan diatas cukup memberikan makna yang signifikan bagi masa depan anak-anak yang dilahirkan diluar perkawinan, karena pokok pikiran dari uraian pertimbangan tersebut menyiratkan maksud bahwa antara status dan kedudukan anak dipisahkan dari segala tindakan dan perbuatan yang dilakukan oleh orang tuanya, artinya negara tetap harus melindungi status hukum si anak meskipun kedua orang tuanya sedang terlibat dalam sengketa tentang keabsahan perkawinannya. Penulis berpendapat bahwa hal itu akan menjadi titik awal lahirnya hukum yang benar-benar dapat memanusiakan manusia, atau dalam arti mendudukan manusia sebagai makhluk ciptaan Tuhan yang memiliki hak dan kedudukan yang sama di muka bumi. Anak merupakan subjek hukum yang tidak memiliki kemampuan untuk mempertahankan kepentingan hokumnya sendiri, sehingga setiap tindakan hukum yang dilakukan oleh seorang anak harus diwakili oleh orang tuanya atau walinya yang sah. Terkait terjadi persengketaan perkawinan yang terjadi pada kedua orang tua si anak, maka anak-anak yang dilahirkan dari perkawinan tersebut tidak boleh menjadi korban dari persengketaan itu. Pasal 28 ayat (2) UU Perkawinan menyebutkan bahwa keputusan tentang pembatalan perkawinan tidak boleh berlaku surut terhadap anakanak yang dilahirkan dari perkawinan tersebut. $^{15}$

Terkait itu, bukan hanya berlaku bagi persengketaan menyangkut masalah pembatalan perkawinan, namun juga harus diartikan terhadap semua persoalan menyangkut keabsahan perkawinan. Artinya sah dan tidaknya perkawinan tersebut tidak selayaknya ditanggung akibatnya oleh si anak yang lahir dari hubungan tersebut. Anak yang dilahirkan tidak pernah mengerti apakah

\footnotetext{
${ }^{15}$ Witanto, op. cit, h. 246.
} 
kelahirannya itu diakibatkan oleh hubungan yang sah ataukah tidak. Pada sudut pandang hak asasi anak, setiap anak yang lahir dengan tidak memperdulikan cara dan bagaimana proses kelahiran itu terjadi, negara dan hukum harus memberikan perlindungan yang adil dengan cara menyediakan kesempatan yang sama bagi setiap anak untuk tumbuh dan berkembang sebagaimana anak-anak pada umumnya. Memang harus difahami lahirnya Pasal 43 ayat (1) UU Perkawinan pada saat itu mungkin belum terpikirkan bahwa seseorang bisa membuktikan secara pasti dan ilmiah tentang silsilah keturunan terhadap anak yang lahir diluar perkawinan, sehingga bukan tidak mustahil ketika si laki-laki merasa keberatan atas anak yang ada di rahim si perempuan dengan mengungkapkan tuduhan bahwa si perempuan telah berhubungan badan dengan laki-laki yang lain selain dirinya, maka akan sulit dipastikan benih siapa yang telah membuahi rahim si perempuan. ${ }^{16}$

Terkait kemajuan jaman, tidak mustahil lagi manusia dapat membuktikan siapa ayah yang telah membenihkannya, dengan sarana teknologi yang ada saat ini orang dapat menentukan siapa penyebab keturunan seseorang, berkaitan dengan hal tersebut, maka cukup adil jika hukum memberikan ruang bagi setiap orang untuk bisa me-

${ }^{16}$ Ibid, h. 247. ngetahui secara pasti atau setidaknya mendekati kepastian siapa sebenarnya ayah yang telah menyebabkan kelahiran seorang anak dan hal itu bisa dijadikan dasar bagi si anak/ibu untuk meminta pertanggungjawaban kepada si ayah untuk memberikan pemeliharaan terhadap anaknya. ${ }^{17}$

\subsection{Konsep Peraturan Kedepan}

Terkait tidak berhaknya anak sumbang sebagai ahli waris orangtua biologisnya, kedepan perlu dipersamakan dengan anak luar kawin lainnya yaitu apabila dapat dibuktikan anak tersebut adalah anak kandung orangtua biologisnya, seharusnya anak sumbang tersebut juga berhak atas harta waris bapak dan ibu biologisnya. Terkait untuk membuktikan hubungan seseorang dengan keluarga pihak ayah bisa dilakukan dengan membandingkan kromosom Y seorang anak dengan ayah kandungnya atau dengan saudara kandung dari pihak ayah. Terkait karena pemeriksaan kromosom Y hanya untuk anak laki-laki, maka untuk melakukan tes DNA pada seorang anak perempuan Tes DNA dilakukan dengan cara mengambil DNA dari kromosom somatik. Ikatan DNA pada bagian somatik hampir sama pada setiap orang karena berfungsi membentuk fungsi dan organ tubuh. Kesalahan urutan dapat menyebabkan gangguan pada manusia yang

\footnotetext{
${ }^{17} \mathrm{Ibid}$
} 
bersangkutan. Tetapi pada inti sel ini pula terdapat area yang dikenal sebagai area STR (short tandern repeats). Area ini tidak memberi kode untuk melakukan sesuatu. STR inilah yang bersifat unik karena berbeda pada setiap orang. Perbedaanya terletak pada urutan pasang basa yang dihasilkan dan urutan pengulangan STR. Urutan AGACC akan berbeda dengan seseorang yang memiliki untaian AGACT. Begitu juga dengan urutan pengulangan yang bersifat unik. Pola STR ini diwariskan dari orang tua. Cara memeriksa tes DNA dilakukan dengan cara mengambil STR dari anak.

Selanjutnya, di laboratorium akan dianalisa urutan untaian STR ini apakah urutannya sama dengan seseorang yang dijadikan pola dari seorang anak. Urutan tidak hanya satu-satunya karena pemeriksaan dilanjutkan dengan melihat nomor kromosom. Misalnya, hasil pemeriksaan seorang anak ditemukan bahwa pada kromosom nomor 3 memiliki urutan AGACT dengan pengulangan 2 kali. Bila ayah atau ibu yang mengaku orang tua kandungnya juga memiliki pengulangan sama pada nomor kromosom yang sama, maka dapat disimpulkan antara 2 orang itu memiliki hubungan keluarga. Seseorang dapat dikatakan memiliki hubungan darah jika memiliki 16 STR yang sama dengan keluarga kandungnya. Bila urutan dan pengulangan sama, maka kedua orang yang dicek memiliki ikatan saudara kandung atau hubungan darah yang dekat. Jumlah ini cukup kecil dibandingkan dengan keseluruhan ikatan spiral dalam tubuh kita yang berjumlah miliaran. ${ }^{18}$

Tes DNA dilakukan dengan mengambil sedikit bagian dari tubuh untuk dibandingkan dengan orang lain. Bagian yang dapat diambil untuk dicek adalah rambut, air liur, urine, cairan vagina, sperma, darah, dan jaringan tubuh lainnya. Sampel ini tidak akan berubah sepanjang hidup seseorang. Penggunaan alkohol, rokok atau obat-obatan tidak akan mengubah susunan DNA. Hasil tes DNA akan dijalankan dari pasien baru dapat dilihat 2-4 minggu. Biaya yang dibutuhkan untuk tes DNA saat ini sekitar 7 hingga 8 juta rupiah. Tes DNA umumnya digunakan untuk 2 tujuan yaitu (1) tujuan pribadi seperti penentuan perwalian anak, tunjangan anak, adopsi, imigrasi, warisan atau penentuan orang tua dari anak dan (2) tujuan hukum, yang meliputi masalah forensik seperti identifikasi korban yang telah hancur, sehingga untuk mengenali identitasnya diperlukan pencocokan antara DNA keluarga korban ataupun untuk korban dengan terduga pembuktian kejahatan semisal dalam kasus pemerkosaan atau pembunuhan.

Berdasarkan uraian di atas, maka Putusan Mahkamah Konstitusi dapat

\footnotetext{
${ }^{18} \mathrm{Ibid}$
} 
menjadi jembatan antara hukum yang ada dengan perkembangan ilmu pengetahuan dan teknologi saat ini, sehingga terbuka ruang bagi anak-anak yang lahir diluar perkawinan untuk mendapatkan haknya dari ayah biologisnya. ${ }^{19}$

Pembuatan bukti ahli waris merupakan hak perdata setiap warga negara, bukan pemberian dari Notaris ataupun dari negara/pemerintah ataupun dari siapapun. Sampai saat ini, belum ada unifikasi hukum (bentuk formalitas sutay dan pejabat atau institusi yang seharusnya atau satu-satunya membuat bukti sebagai ahli waris). Indonesia sebagai sebuah negara yang merdeka, sudah seharusnya mengakhiri adanya distingsi dan diskriminasi mengenai bermacam-macam bentuk formalitas dan siapa yang harus membuat bukti sebagai ahli waris tersebut. Terkait untuk menghilangkan dan menghapus diskriminasi dalam bentuk formal dan pejabat/institusi yang membuat bukti ahli waris untuk Warga Negara dan penduduk Indonesia, maka notaris dapat berperan sebagai satusatunya pihak yang dapat membuat bukti sebagai ahli waris tersebut. Sebagai notaris yang hidup dalam sebuah negara yang merdeka, notaris harus secara aktif ikut serta mengimplementasikan nilai-nilai kemerdekaan dalam suatu tindakan nyata. Notaris harus siap menjadi agen pem-

\footnotetext{
${ }^{19}$ Ibid, h. 235.
}

baharuan dan satu-satunya pejabat yang berwenang untuk membuat bukti ahli waris dalam bentuk formal akta pihak untuk seluruh Warga Negara Republik Indonesia, tanpa berdasarkan golongan/ etnis/suku ataupun agama. $^{20}$

Penggolongan penduduk dan hukum yang berlaku untuk setiap golongan penduduk seharusnya sudah tidak ada lagi, tetapi dalam kenyataannya masih diberlakukan, antara lain telah dijadikan dasar hukum dalam pembuatan bukti sebagai ahli waris. Pemberlakuan ketentuan ini merupakan tindakan diskriminatif sekaligus rasialis, dan melanggar prinsip-prinsip hak asasi manusia, dengan demikian, aturan hukum dalam pembuatan bukti sebagai ahli waris yang masih harus berdasarkan etnis dan institusi yang membuatnya berbeda harus segera diakhiri, disamping itu tidak ada akibat hukum apapun dengan adanya pembedaan bukti ahli waris berdasarkan etnis. $^{21}$

Pembuatan keterangan hak waris oleh seorang notaris bagi orang-orang yang tunduk pada KUH Perdata tidak ada dasar hukumnya dalam hukum tertulis yang berlaku di Indonesia. Terkait itu, selama ini SKW untuk etnis/golongan penduduk eropa, cina, timur asing tidak mempunyai landasan hukum (berdasarkan hukum

\footnotetext{
${ }^{20}$ Ibid, h. 34.

${ }^{21}$ Ting Swan Tiong, Pembuktian Hak Atas Harta Peninggalan (Jakarta: Media Notariat, 1988), h. 115
} 
positif) sama sekali, tetapi tindakan hukum tersebut hanya merupakan kebiasaan notaris sebelumnya yang kemudian diikuti notaris berikutnya apa adanya, tanpa mengkaji lebih jauh kewenangan notaris untuk membuat SKW. Bahkan tindakan notaris seperti itu dapat dikualifikasikan sebagai tindakan diluar wewenang notaris. ${ }^{22}$

Dasar hukum bahwa notaris dapat menjadi satu-satunya pejabat institusi yang berwenang untuk membuat bukti ahli waris untuk semua masyarakat Indonesia, tidak berdasarkan etnis dan golongan, agama apapun, yaitu berdasarkan kewenangan notaris yang tersebut dalam Pasal 15 ayat 1 UUJN, yaitu membuat akta. Kehadiran UUJN tersebut sampai saat ini satu-satunya undang-undang yang mengatur notaris Indonesia yang berarti telah menjadi unifikasi hukum dalam bidang pengaturan notaris. UUJN dapat disebut sebagai penutup masa lalu dunia notaris Indonesia dan pembuka dunia notaris Indonesia masa datang. Saat ini UUJN saja yang merupakan "rule of law" untuk dunia Notaris Indonesia.

Penjelasan umum UUJN ditegaskan bahwa peraturan perundang-undangan yang mengatur tentang notaris sudah tidak sesuai lagi dengan perkembangan dan kebutuhan hukum masyarakat Indonesia. Terkait itu, perlu diadakan pembaharuan dan pengaturan kembali secara menyeluruh dalam satu undang-undang yang mengatur tentang jabatan notaris sehingga tercipta suatu unifikasi hukum yang berlaku untuk semua penduduk di seluruh wilayah negara Republik Indonesia. Terkait rangka mewujudkan unifikasi hukum di bidang kenotariatan tersebut dibentuk undangundang tentang jabatan notaris. ${ }^{23}$

SKW yang selama ini dibuat oleh para notaris berdasarkan kebiasaan yang tidak ada dasar hukumnya sama sekali, dengan menggunakan ukuran sebagaimana yang tersebut dalam Pasal 38 UUJN, maka SKW tidak memenuhi syarat untuk disebut sebagai akta notaris, tapi hanya berupa pernyataan notaris berdasarkan bukti-bukti yang disodorkan kepada notaris. Menurut Tan Thong Kie, pembuatan SKW oleh para notaris tidak ada peraturan perundangundangan yang mendasarinya. ${ }^{24}$

SKW hanya merupakan surat dibawah tangan yang dibuat oleh notaris, yang nilai pembuktiannya tidak sempurna, dan sama nilainya dengan surat-surat lain (untuk keperluan administrasi kantor notaris) yang biasa dikeluarkan oleh notaris. Terkait itu, jika notaris mengeluarkan SKW yang seakan-akan mempunyai kekuatan pembuktian seperti akta, hal tersebut sudah diluar wewenang notaris. Notaris sebagai

\footnotetext{
${ }^{23}$ Ibid, h. 35 .

${ }^{24}$ Tan Thong Kie, Serba-Serbi Praktek Notaris (Jakarta: Ichtiar Baru Van Hoeve, 1994), h. 362
} 
pejabat/institusi satu-satunya yang berhak membuat bukti sebagai ahli waris tersebut, sangat tepat jika dibuat dengan akta pihak, sebagai bentuk pernyataan atau keterangan kehendak para pihak untuk menuangkan hak-hak dan susunan ahli waris dengan akta notaris dalam bentuk akta pihak. Terkait hal ini dapat dilakukan di masa depan, secara langsung dapat untuk mengembalikan jenis akta otentik yang dibuat oleh/dihadapan notaris yaitu akta pihak dan akta relaas, sehingga tidak ada jenis akta otentik lain selain dua tersebut. ${ }^{25}$

Pada segi pembuktian, akta keterangan ahli waris mempunyai nilai bukti yang sempurna karena dibuat di hadapan pejabat yang berwenang (Notaris), tapi SKW tidak mempunyai kekuatan pembuktian yang sempurna, meskipun dibuat oleh notaris, karena tidak memenuhi syarat sebagai akta dan bukan wewenang notaris. Kemudian akta keterangan ahli waris jika ternyata isinya tidak benar, maka hal tersebut merupakan tanggung jawab para pihak yang menghadap notaris, dan tidak perlu melibatkan notaris dan jika akan diperbaiki, maka akta keterangan ahli waris yang sebelumnya harus dicabut oleh mereka yang membuatnya dan kemudian dibuat akta baru sesuai fakta yang sebenarnya yang diinginkan oleh para pihak.

\footnotetext{
${ }^{25}$ Habib Adjie, Sanksi Perdata dan Administratif Terhadap Notaris Sebagai Pejabat Publik (Bandung: Refika Aditama, 2008), h. 40.
}

Sedangkan jika SKW isinya tidak benar, maka tidak mungkin notaris akan mencabut atau membatalkan SKW yang telah dibuatnya sendiri, dan sudah tentu harus ada pihak yang mengajukan permohonan kepada notaris yang membuatnya, agar SKWnya dibatalkan. Terkait notaris tidak mau mencabutnya maka pencabutannya harus dengan cara mengajukan gugatan terhadap notaris dan notaris dapat dituntut ganti rugi. $^{26}$

Akta keterangan ahli waris merupakan kehendak para pihak untuk membuktikan dirinya sebagai ahli waris, karena dinyatakan di hadapan notaris, maka sesuai dengan kewenangan notaris sebagaimana yang tersebut dalam UUJN, wajib untuk memformulasikannya dalam bentuk akta notaris. Terkait itu, kehendakan para pihak diformulasikan dalam bentuk akta keterangan ahli waris. Notaris tidak mempunyai kehendak untuk membuat akta untuk orang lain, dan notaris tidak akan membuat akta apapun jika tidak ada permintaan atau kehendak dari para pihak, dan notaris bukan pihak dalam akta, dengan demikian notaris tidak akan pernah membuat akta keterangan ahli waris jika tidak ada permintaan dan kehendak dari para pihak. Notaris harus segera untuk berusaha menghentikan paradigma bahwa hukum Indonesia disusun dan dibuat untuk

\footnotetext{
${ }^{26}$ Ibid, h. 41.
} 
kepentingan etnis/golongan/suku bangsa tertentu. Bahkan dikalangan notaris sendiri seperti tidak ada upaya untuk menghilangkan diskriminasi dalam pembuatan bukti ahli waris tersebut, dan seakan-akan para notaris masih berada dalam kondisi yang harus dibedakan di hadapan hukum.

Berdasarkan kewenangan yang ada pada notaris sudah saatnya untuk berada selangkah di depan dalam mengantisipasi kemajuan zaman dan melakukan pembaharuan. Jika hal tersebut mampu para notaris lakukan, maka akan merupakan kontribusi notaris untuk turut serta membangun unifikasi hukum, setidaknya sebagai institusi satu-satunya yang berhak membuat bukti formal sebagai ahli waris dalam bentuk akta pihak untuk seluruh lapisan masyarakat Indonesia. ${ }^{27}$

Terkait tidak diaturnya kewenangan notaris dalam membuat SKW dalam UUJN membuat notaris tidak mempunyai kepastian hukum dalam pembuatan SKW, karena kepastian hukum merupakan salah satu tujuan hukum dan dapat dikatakan sebagai upaya mewujudkan keadilan. Kepastian adalah perihal (keadaan) yang pasti. Hukum secara hakiki harus pasti dan adil. Kepastian hukum merupakan pertanyaan yang hanya bisa dijawab secara normatif bukan sosiologi. Kepastian hukum secara normatif adalah ketika suatu

\footnotetext{
${ }^{27}$ Ibid, h. 42.
}

peraturan dibuat dan diundangkan secara pasti karena mengatur secara pasti dan logis. ${ }^{28}$ Sedangkan, terkait kewenangan notaris dalam membuat SKW tidak terdapat dalam UUJN atau peraturan perundangundangan lainnya.

Kepastian hukum sebagai salah satu tujuan hukum dan dapat dikatakan upaya mewujudkan keadilan. Bentuk nyata dari kepastian hukum adalah pelaksanaan dan penegakan hukum terhadap suatu tindakan tanpa memandang siapa yang melakukan. Adanya kepastian hukum setiap orang dapat memperkirakan apa yang akan terjadi jika melakukan tindakan hukum itu. Kepastian sangat diperlukan untuk mewujudkan keadilan. Kepastian salah satu ciri yang tidak dapat dipisahkan dari hukum, terutama untuk norma hukum tertulis. Hukum tanpa nilai kepastian akan kehilangan makna karena tidak dapat di gunakan sebagai pedoman perilaku bagi setiap orang. Kepastian merupakan ciri yang tidak dapat dipisahkan dari hukum, terutama untuk norma hukum tertulis. kepastian sendiri disebut sebagai salah satu tujuan dari hukum. Peringkat analisis yang fundamental untuk menentukan baik buruknya aturan hukum atau sistem hukum adalah peringkat analisis moral. ${ }^{29}$

28 C.S.T Kansil, Kamus Istilah Hukum (Jakarta: Gramedia Pustaka, 2009), h. 385

${ }^{29}$ Ibid, h. 270 


\section{KESIMPULAN}

Konsep kedepan terhadap kewenangan notaris dalam membuat surat keterangan hak waris bagi anak yang dilahirkan pada hubungan sedarah (anak Sumbang) adalah dengan membuat peraturan terkait siapa yang berhak membuat atau mengesahkan surat keterangan waris, yaitu notaris yang mempunyai kewenangan berdasarkan Pasal 15 UUJN dalam membuat akta otentik dan mengesahkan akta dibawah tangan, mengingat selama ini belum ada peraturan yang berkepastian hukum terkait siapa yang berhak dalam membuat surat keterangan waris.

\section{DAFTAR PUSTAKA}

\section{Buku}

Gede Afriliana Saputra, Dasar Hukum Notaris dalam Pembuatan Surat Keterangan Waris, Jurnal Ilmiah Prodi Magister Kenotariatan.

Habib Adjie. 2008. Sanksi Perdata dan Administratif Terhadap Notaris Sebagai Pejabat Publik. Bandung: Refika Aditama.

Herowati Poesoko, Diktat Mata Kuliah Metode Penulisan dan Penelitian Hukum, Fakultas Hukum Universitas Jember, 2012.

Maria Farida. 2002. Ilmu PerundangUndangan, Dasar-Dasar dan Pembentukannya. Yogyakarta: Kanisius.
Ritna Makdalena. Tinjauan Yuridis Tentang Perkawinan Sedarah Menurut UU Nomor 1 Tahun 1974, Jurnal Lex Privatum, Vol. VI, No. 2, 2018

Tan Thong Kie. 1994. Serba-Serbi Praktek Notaris. Jakarta: Ichtiar Baru Van Hoeve.

Ting Swan Tiong. 1988. Pembuktian Hak Atas Harta Peninggalan. Jakarta: Media Notariat.

Witanto. 2008. Tanggung Jawab Notaris dalam Membuat Surat Keterangan Hak Waris. Jakarta: Tesis,

\section{Peraturan Perundang-undangan}

Undang Dasar Republik Indonesia Tahun 1945

Kitab Undang-Undang Hukum Perdata

Undang-Undang Nomor 30 Tahun 2004 tentang Jabatan Notaris sebagaimana telah diubah dengan Undang-Undang Nomor 2 Tahun 2014 tentang Jabatan Notaris

\section{BIODATA SINGKAT PENULIS}

Amalia Putri Vairus adalah mahasiswa Program Studi Magister Kenotariatan di Fakultas Hukum Universitas Jember 